Ekonomia - Wroclaw Economic Review 24/2 (2018)

Acta Universitatis Wratislaviensis

No 3858

DOI: 10.19195/2084-4093.24.2.5

Olga Komorowska

ORCID: 0000-0002-0305-8748

Uniwersytet Gdański

Wydział Zarządzania

olga.komorowska@ug.edu.pl

\title{
Aktywność życiowa rodziców wychowujących dziecko z niepełnosprawnością jako istotny element ochrony ich zdrowia
}

Artykuł nadesłany: 12 listopada 2017 r.; artykuł zaakceptowany: 20 kwietnia 2018 r.

JEL Classification: J14, J18, J15, J17

Keywords: family with a child with a disability, professional activity, life activity, family support

\section{Abstract}

Life activity of parents raising a child with a disability as an important element of their health protection

Diagnosis of a child's disability becomes a cause of stress that applies to the whole family, above all the mother, who most often deals with the care and upbringing of the child. Disability absorbs the physical and mental resources in the family, because much of the attention is focused on the child. Parents, and above all mothers, are tired both physically and mentally. Life activity, understood as professional activity, as well as spending free time away from home, enables disengagement from the child's disability, which may have a beneficial effect on the improvement of well-being.

The aim of the article is to present the professional activity of parents bringing up a child with disabilities, free time, tourism, and leisure outside the place of residence. The study was based on unpublished data from the Household Budget Survey (BBGD 2014) and data from the study "Entrepreneurial and Consumer Behaviors in Families Caring for Children and Teenagers with Disabilities" financed by the National Center for Science (OPUS 4) and individual interviews. 


\section{Wstęp}

Rodzina po otrzymaniu diagnozy o niepełnosprawności dziecka musi dostosować się do nowych obowiązków i wyzwań związanych z opieką nad nim i jego rehabilitacją (Komorowska 2014; Kosmalowa 2007, s. 109-115). Aktywność życiowa jej członków ulega zmianom, niejednokrotnie w kierunku zmniejszenia aktywności zawodowej lub całkowitej z niej rezygnacji, ograniczenia kontaktów towarzyskich oraz wyjazdów wypoczynkowych na rzecz pozostania w domu lub wyjazdu na turnus rehabilitacyjny.

Aktywność życiowa jest w niniejszym artykule rozumiana jako aktywność zawodowa i spędzanie czasu wolnego poza domem. Aktywność fizyczna i umysłowa poprawia stan emocjonalny człowieka i obniża poziom jego stresu (Truszkowska-Wojtkowiak 2012, s. 196-212), co w wypadku rodziców wychowujących dziecko z niepełnosprawnością ma bardzo duże znaczenie. Dorośli ci podlegają bardzo dużemu stresowi, który jest związany zarówno z samą niepełnosprawnością ich potomka, jak i z potrzebą organizowania wsparcia dla dziecka. Codzienna rehabilitacja, obserwacja postępów dziecka (lub ich brak), niepokój związany z przyszłością dziecka ${ }^{1}$, niemożność załatwienia niektórych spraw - to tylko niektóre z wielu czynników, z którymi borykają się rodzice (Komorowska 2016, s. 31-34). Należy w tym miejscu również nadmienić, że rodzice dzieci z niepełnosprawnością doświadczają obciążenia psychicznego, lecz także fizycznego. W przypadku dziecka niepełnosprawnego ruchowo rodzic musi bowiem wspierać je podczas wstawania z łóżka, siadania na wózku rehabilitacyjnym, ale też w wypadku korzystania z toalety. Rodzicowi dziecka z niepełnosprawnością trudno również pogodzić pracę i opiekę nad dzieckiem (Kubicki 2016, s. 13-15).

Praca zawodowa należy do najważniejszych czynników pozycji społecznej (Giddens 2008, s. 305-319; Gitling 2013, s. 211-221). Jest to ponadto źródło środków finansowych na życie. W wypadku rodzin wychowujących dzieci z niepełnosprawnością podjęcie aktywności zawodowej należy potraktować również jako wsparcie psychiczne rodziców, ponieważ praca umożliwia oderwanie się od niepełnosprawności dziecka i nabrania dystansu do swojego życia. Często jednak rodzic, przede wszystkim matka, poświęca się całkowicie opiece nad dzieckiem, przez co rezygnuje z pracy.

Praca oraz wypoczynek określają aktywność życiową człowieka. Celem niniejszego artykułu jest przedstawienie aktywności zawodowej rodziców wychowujących dziecko z niepełnosprawnością oraz ich czasu wolnego (także

${ }^{1}$ Co trzecia osoba w badaniu przeprowadzonym w ramach projektu „Zachowania przedsiębiorcze i konsumpcyjne w rodzinach opiekujących się dziećmi i młodzieżą z niepełnosprawnością" (NCN OPUS 5) martwiła się o przyszłość dziecka, gdy zabraknie rodziców. Na tym samym poziomie był odsetek odpowiedzi dotyczący zmartwień, że dziecko będzie źle traktowane przez rówieśników. 
w obszarze turystyki i wypoczynku). W tekście wykorzystano dane jednostkowe Badania Budżetów Gospodarstw Domowych (BBGD 2014) oraz dane z badania „Zachowania przedsiębiorcze i konsumpcyjne w rodzinach opiekujących się dziećmi i młodzieżą z niepełnosprawnością" finansowanego ze środków Narodowego Centrum Nauki (OPUS 5). W artykule zostały także wykorzystane fragmenty wywiadów przeprowadzonych przez autorkę.

\section{Czas dla rodzica}

Aktywność życiową rodzice mogą zazwyczaj podejmować, gdy ich dziecko znajduje się pod czyją́s opieką lub gdy jest na tyle samodzielne, że może zostać samo w domu. Na wykresie 1 widać, że około $62 \%$ matek wychowujących dziecko z niepełnosprawnością, biorących udział w badaniu ,Zachowania przedsiębiorcze i konsumpcyjne w rodzinach opiekujących się dziećmi i młodzieżą z niepełnosprawnością" określiło, że gdy dziecko jest w okresie przedszkolno-szkolnym, jest ono pod opieką instytucji 4-8 godzin w ciągu dnia. Jeśli dziecko uczęszcza do przedszkola lub do szkoły, czas, który w niej spędza, rodzic (najczęściej matka) może poświęcić sobie. Należy zwrócić uwagę, że w pewnym wieku dzieci pełnosprawne same wracają do domu, ponieważ są samodzielne. W wypadku dziecka z niepełnosprawnością intelektualną taka chwila najczęściej nie nadejdzie. Matka, jeżeli chce pracować, musi więc swoją aktywność życiową dostosować do potrzeb dziecka oraz do wymogów instytucjonalnych, na przykład godzin przywożenia dziecka do domu przez transport miejski.

Beata: Nie pracuję. Mieszkam 8 km od miasta, w którym dzieci chodzą do szkoły. Mam dwoje dzieci z niepełnosprawnością. Starszy syn ma autyzm, młodsza córka ma zespół Downa. Zawożę je do szkoły. Nie wracam do domu, bo mi się nie opłaca. Czekam do 12 i zabieram je do domu. Między 8 a 12 pomagam jako wolontariusz w fundacji dla dzieci z niepełnosprawnością. Czuję się zmęczona niepełnosprawnością. Bo ciągle mnie otacza. Ale nie mogę pójść na etat do pracy. Zbyt często by mnie nie było, a poza tym pracodawca wymagałby pełnej dyspozycyjności i pracy na pełen etat. W tym roku dwoje dzieci jedzie na kolonie, mam nadzieję, że pojadą w tym samym czasie. Wtedy odpocznę. W domu nie odpoczywam, bo mam dwójkę dzieci z niepełnosprawnością do ogarnięcia. Wieczorem padam i nie mam na nic siły².

Ewelina: Zawożę Julkę do szkoły. Nie chcę, żeby jechała z dowozem miejskim, bo będzie długo jechała. Dowóz musi zbierać po kolei wszystkie dzieci. A tak jedzie prosto do szkoły. Do 12 mam czas. Wtedy pracuję. Dobrze, że mam pracę, której czas mogę sama sterować. Prowadzę działalność gospodarczą. Odbieram Julkę i jedziemy na rehabilitację. Musi codziennie ćwiczyć, w przeciwnym wypadku choroba będzie postępować. Jeszcze mam syna, który też potrzebuje mojej uwagi. Potem mam czas, gdy dzieci są w łóżkach, po 20:30. Dzieci same jeszcze nie wyjeżdżały. Julka nie pojedzie na wakacje beze mnie. Syn już niedługo tak.

2 Wywiady osobiste zostały przeprowadzone przez autorkę w 2016 roku w ramach badania OPUS 5, a następnie w 2017 roku. 
Basia: Piotrek jest bardzo długo w szkole. Odbierany jest jako pierwsze dziecko, dlatego spędza 45 minut w busie. Przyjeżdżam po niego do szkoły, gdy skończę pracę, dlatego jest w szkole od 8 rano do godziny 17. Do domu jedziemy ze szkoły pół godziny, ponieważ szkoła specjalna jest tak daleko. W domu jest o 17:30. Samotnie wychowuję syna, dlatego muszę pracować.

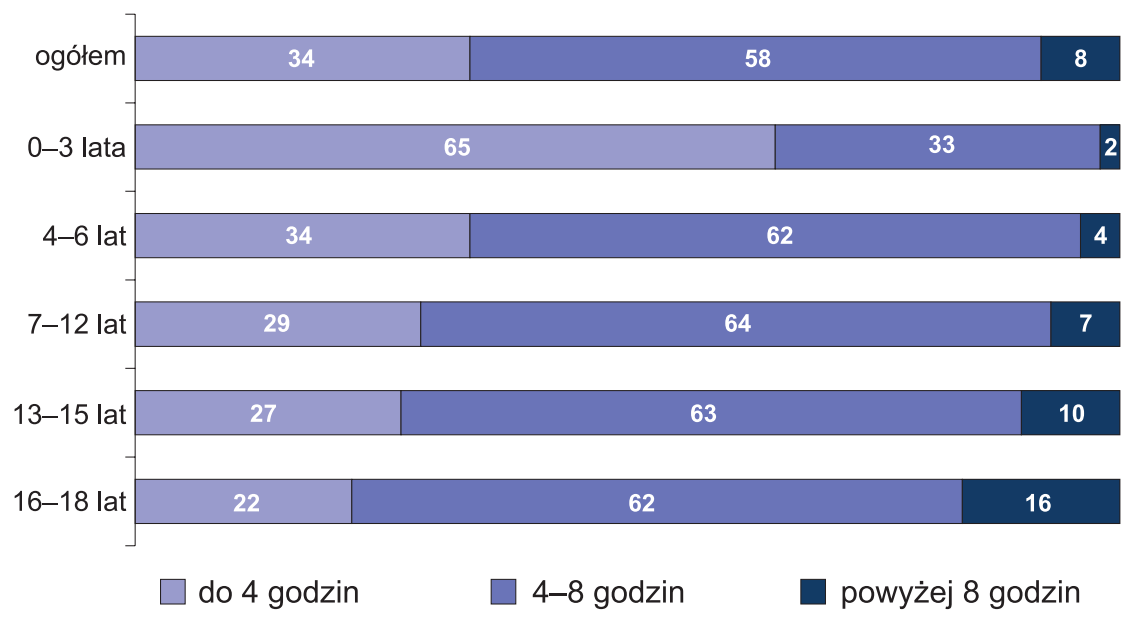

Wykres 1. Średnia liczba godzin, w których dziecko z niepełnosprawnością było pod opieką instytucji (na przykład przedszkole, szkoła) w dni robocze w 2014 roku

Źródło: opracowanie własne na podstawie danych z badania „Zachowania przedsiębiorcze i konsumpcyjne w rodzinach opiekujących się dziećmi i młodzieżą z niepełnosprawnością".

Rodzice dzieci z niepełnosprawnością deklarują bardzo niewielką aktywność w weekendy oraz w święta (wykres 2). Co trzecia osoba (27\%) 4 razy lub więcej w ciągu roku spotkała się na forum rodzinnym lub towarzysko, natomiast $73 \%$ - mniej niż 4 razy, czyli rzadziej niż raz na kwartał. Jedynie 23\% określiło, że korzysta z aktywnej rekreacji w pobliżu domu 4 razy lub więcej w ciągu roku. Aż 37\% respondentów podało, że nie wyjechało nigdzie bez dziecka z niepełnosprawnością, z kolei $63 \%$ skorzystało z takiej możliwości odpoczynku. Warto podkreślić, że prawie połowa respondentów (48\%) niekorzystających z aktywności, które zostały wymienione na wykresie 2, za przyczynę swojej bierności podało brak pieniędzy. Po mniej więcej $20 \%$ respondentów jako przyczynę nieaktywności w tym obszarze wskazało brak dobrych pomysłów, brak ciekawych propozycji ze strony rodziny i znajomych, potrzebę zostania w domu i zaopiekowania się swoim niepełnosprawnym dzieckiem. 
P62. Czy w ciągu ostatniego roku (2014 i 2015 do dzisiaj) uczestniczył Pan/i Pani w następujących rodzajach aktywności w weekendy/święta, Jeśli tak, to ile razy?

Wyjście na spotkanie rodzinne/towarzyskie

W aktywnej (fizycznej) rekreacji w pobliżu własnego domu (we własnej miejscowości) - basen, rower, spacery, biegi, nordic walking, inne zajęcia tego typu

Wyjazd z rodziną (i z dzieckiem niepełnosprawnym) poza miejsce stałego zamieszkania (do innej miejscowości: do rodziny, na działkę, do ośrodka wypoczynkowego, do hotelu itp.), $\mathrm{z}$ noclegiem

Wyjście do kina, teatru, muzeum, na koncerty, wystawy

Wyjazd z rodziną (bez dziecka niepełnosprawnego) poza miejsce stałego zamieszkania (do innej miejscowości: do rodziny, na działkę, do ośrodka wypoczynkowego, do hotelu itp.), $z$ noclegiem

$\square$ (brak aktywności) $\square 1$ raz

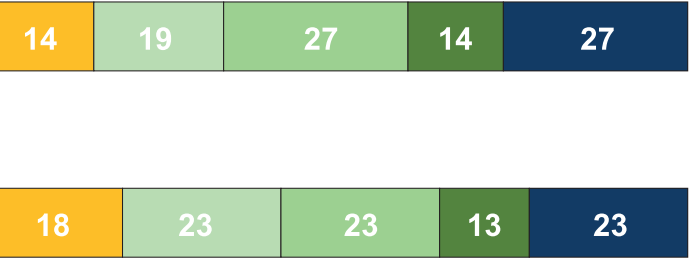

\begin{tabular}{|l|l|l|l|l|}
\hline 20 & 27 & 32 & 8 & 12 \\
\hline
\end{tabular}

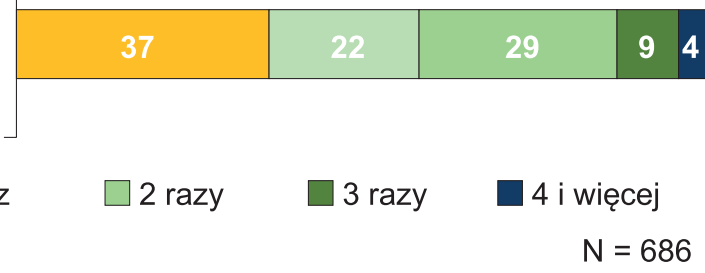

Wykres 2. Częstotliwość korzystania z wybranych aktywności w weekendy i święta w ciągu ostatniego roku

Źródło: opracowanie własne na podstawie danych z badania „Zachowania przedsiębiorcze i konsumpcyjne w rodzinach opiekujących się dziećmi i młodzieżą z niepełnosprawnością".

W BBGD 2014 respondenci mieli określić stopień zaspokojenia różnych potrzeb. Jedną z nich była potrzeba wyjścia do teatru, na koncerty albo do kina, którą GUS określił jednym słowem jako „kultura”. W tabeli 1 przedstawiony został poziom zaspokojenia tej potrzeby, w podziale na gospodarstwa z dzieckiem z niepełnosprawnością oraz na gospodarstwa z dziećmi bez niepełnosprawności. Potrzebę tę jako zaspokojoną na poziomie pozytywnym (dobrze, raczej dobrze) oceniło $44 \%$ gospodarstw z dzieckiem bez niepełnosprawności. W wypadku gospodarstw z dzieckiem niepełnosprawnym odsetek gospodarstw oceniających stopień zaspokojenia tej potrzeby był o 20 p.p. niższy. Z kolei potrzebę tę jako zaspokojoną na niskim poziomie (raczej źle, źle) określiło $22 \%$ gospodarstw z dzieckiem bez niepełnosprawności. W przypadku gospodarstw z dzieckiem niepełnosprawnym 
odsetek gospodarstw oceniających stopień zaspokojenia tej potrzeby był wyższy i wynosił 38\%. Jak można zauważyć, potrzeba ta jest gorzej zaspokojona w grupie gospodarstw $\mathrm{z}$ dzieckiem $\mathrm{z}$ niepełnosprawnością $\mathrm{w}$ porównaniu z gospodarstwami z dziećmi bez niepełnosprawności.

Jako miernik stopnia zaspokojenia potrzeb w BBGD 2014 została przyjęta średnia arytmetyczna ${ }^{3}$. W wypadku gospodarstw z dziećmi bez niepełnosprawności wskaźnik zaspokojenia potrzeb kulturalnych był na poziomie 4,3, natomiast w drugiej grupie porównawczej był niższy i wynosił 3,7.

Tabela 1. Poziom zaspokojenia potrzeby kultury (\% gospodarstw)

\begin{tabular}{l|c|c|c|c|c|c}
\hline \multirow{2}{*}{ Rodzaj gospodarstwa } & \multicolumn{7}{c}{ Ocena } \\
\cline { 2 - 7 } & dobrze & $\begin{array}{c}\text { raczej } \\
\text { dobrze }\end{array}$ & $\begin{array}{c}\text { przeciętnie; } \\
\text { ani dobrze, } \\
\text { ani źle }\end{array}$ & $\begin{array}{c}\text { raczej } \\
\text { źle }\end{array}$ & źle & $\begin{array}{c}\text { nie } \\
\text { dotyczy }\end{array}$ \\
\hline $\begin{array}{l}\text { z dziećmi bez } \\
\text { niepełnosprawności }\end{array}$ & 21,7 & 22,0 & 32,3 & 14,6 & 7,4 & 2,0 \\
\hline $\begin{array}{l}\text { z dzieckiem z nie- } \\
\text { pełnosprawnością }\end{array}$ & 10,9 & 13,1 & 35,1 & 23,0 & 15,4 & 2,6 \\
\hline
\end{tabular}

Źródło: opracowanie własne na podstawie nieopublikowanych danych z BBGD 2014.

\section{Turystyka i wypoczynek}

Człowiek musi odpoczywać, żeby zregenerować siły do dalszej pracy. Kodeks pracy przewiduje dla pracowników zarówno odpoczynek dobowy, jak i w ciągu roku. W art. 162 k.p. jest zapisane, że co najmniej jedna część wypoczynku nie może trwać krócej niż 14 kolejnych dni kalendarzowych. W wypadku przeciążenia zadaniami może bowiem pojawić się wypalenie zawodowe. Jeżeli natomiast chodzi o rodziców opiekujących się dzieckiem z niepełnosprawnością, to często dochodzi u nich do zjawiska tak zwanego wypalenia się sił. Rodzic czuje wówczas zmęczenie nie tylko fizyczne, lecz także psychiczne (Bujak 2013, s. 112-118; Sekułowicz, Kwiatkowski 2013, s. 29-50).

Wykres 3 pokazuje liczbę wyjazdów respondentów badania „Zachowania przedsiębiorcze i konsumpcyjne w rodzinach opiekujących się dziećmi i młodzieżą z niepełnosprawnością" w ciągu 2014 roku poza miejsce zamieszkania. Prawie $40 \%$ osób stwierdziło, że nie wyjechało ani razu, co świadczy o braku wypoczynku. Spośród badanych, którzy nie wyjechali, 70\% stwierdziło, że powodem był

3 Średnia arytmetyczna jest miarą przeciętnego poziomu zmiennej, będącą wypadkową wszystkich wartości cechy i jest wrażliwa na wartości skrajne. Stosuje się ją w wypadku cech ilościowych. W przypadku oceny stopnia zaspokojenia potrzeb wartość mediany nie oddałaby w pełni charakteru miernika, jakim jest stopień zaspokojenia potrzeb. 
brak pieniędzy, dla $24 \%$ był to braku urlopu, a dla $14 \%$ — że jest to zbyt trudne i zbyt męczące przedsięwzięcie.

P65. Ile razy w ciągu 2014 roku wyjeżdżał/a Pan/Pani poza miejsce swojego stałego zamieszkania na dłuższy wypoczynek (wakacje, urlop) przynajmniej z 4 noclegami

P66. lle razy w tych wyjazdach uczestniczyło niepełnosprawne dziecko

Liczba wyjazdów w 2014 roku poza miejsce zamieszkania

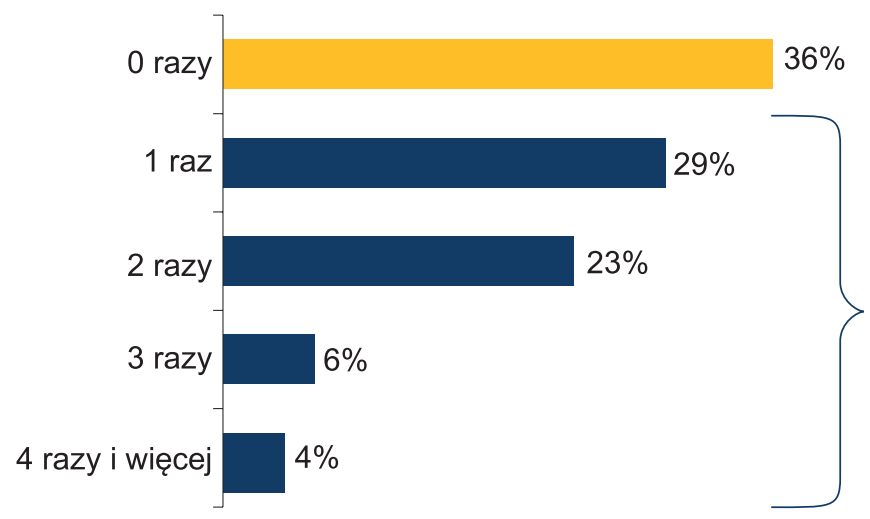

Wykres 3. Liczba wyjazdów w 2014 r. poza miejsce zamieszkania

Źródło: opracowanie własne na podstawie danych z badania „Zachowania przedsiębiorcze i konsumpcyjne w rodzinach opiekujących się dziećmi i młodzieżą z niepełnosprawnością".

W wypadku dzieci z niepełnosprawnością intelektualną mogą się zdarzać sytuacje, w których rodzice poświęcają swój urlop wypoczynkowy na zajęcie się dzieckiem podczas wakacji, co w przypadku jednoczesnego wykonywania obowiązków pracowniczych i zadań związanych z opieką nad dzieckiem powoduje, że rodzic nie jest w stanie zregenerować swoich sił.

Magda: Brakuje w wakacje półkolonii dla dzieci niepełnosprawnych. Mój urlop i urlop mojego męża nie pokrywa połowy wolnych dni, jakie ma syn w szkole. Musimy jeszcze wykorzystać urlop babci i wspomóc się jeszcze opiekunką. Zajęcia dzienne są dla wszystkich innych dzieci, ale nie dla dzieci niepełnosprawnych. Prosiliśmy naszą szkołę, żeby coś zorganizowała, ale ponieważ szkoła jest stara, w wakacje są remonty. Nie wyjeżdżamy wspólnie na wakacje. Jedynie w weekendy. Staram się tak zorganizować czas, żeby mój syn miał wspomnienia z wakacji, np. idziemy do zoo, jedziemy nad jezioro ${ }^{4}$.

Jak wynika z tabeli 2, im dziecko jest starsze, tym częściej wyjeżdża w celach turystycznych bez opiekunów i na dłużej. Jednak praktycznie co piąty nastolatek z niepełnosprawnością nie wyjechał ani razu bez rodziców w ciągu roku $(28 \%$ dzieci w wieku 13-15, 23\% dzieci w wieku 16-18 lat). Wynika z tego, że rodzice sprawują nad nimi ciągłą opiekę bez możliwości wypoczynku w zasadzie przez całe ich życie. Należy zauważyć, że w rodzinach z dziećmi bez niepełnosprawnokułu.

${ }^{4}$ Wywiad przeprowadzony w 2010 roku w ramach badań do pracy doktorskiej autorki arty- 
ści młodzież w tym wieku wyjeżdża już sama na obozy i kolonie, staje się samodzielna. 57\% dzieci niepełnosprawnych z rodzin osób pracujących w 2014 roku wyjechało bez opieki rodziców ze szkołą, przedszkolem lub ośrodkiem wychowawczym. W grupie dzieci z rodzin osób niepracujących ten odsetek był znacząco mniejszy i wynosił $46 \%$.

Tabela 2. Liczba wyjazdów dziecka w 2014 roku poza dom w celach turystycznych/wypoczynkowych z co najmniej 1 noclegiem bez udziału rodziców/opiekunów na co dzień odpowiedzialnych za dziecko

\begin{tabular}{l|c|c|c|c}
\hline \multicolumn{1}{c|}{ Liczba wyjazdów } & ani razu & 1 raz & 2 razy & $\begin{array}{c}3 \text { razy } \\
\text { i więcej }\end{array}$ \\
\cline { 1 - 1 } Wiek dziecka & $50 \%$ & $25 \%$ & $15 \%$ & $10 \%$ \\
\hline 0-3 lata & $52 \%$ & $17 \%$ & $14 \%$ & $17 \%$ \\
\hline 7-6 lat & $34 \%$ & $29 \%$ & $21 \%$ & $16 \%$ \\
\hline 13-15 lat & $28 \%$ & $25 \%$ & $20 \%$ & $26 \%$ \\
\hline $16-18$ lat & $23 \%$ & $35 \%$ & $20 \%$ & $22 \%$ \\
\hline
\end{tabular}

Źródło: opracowanie własne na podstawie danych z badania „Zachowania przedsiębiorcze i konsumpcyjne w rodzinach opiekujących się dziećmi i młodzieżą z niepełnosprawnością".

W wypadku rodziców dzieci z niepełnosprawnością turnus rehabilitacyjny, na który można uzyskać dofinansowanie, jest traktowany przez niektórych z nich jako forma wypoczynku, mimo że dziecko jest tam rehabilitowane i trzeba przestrzegać reguł czasowych. Jednak nie wszyscy rodzice uważają, że turnus rehabilitacyjny pozwala wypocząć.

Jadwiga: Ja na turnusach rehabilitacyjnych wypoczywam. Nie muszę gotować (i już samo to jest boskie), chodzić do pracy, ogarniać tego całego bałaganu. Przebywam z ludźmi, którzy wiele rozumieją bez słów. Na basen sobie pochodzę, masaż jakiś się trafi, czegoś przydatnego się dowiem, wyśmieję za wszystkie czasy, naładuję baterie. Przy tym poziomie stresu, który mają na co dzień rodzice niepełnosprawnych dzieci, to jest bezcenne. Gdybym miała fundusze, to na pewno jeździłabym raz w roku.

Teresa: Ja na początku w ogóle nie jeździłam na turnusy rehabilitacyjne. Stwierdziłam, że syn ma na co dzień tyle zajęć i terapii, że nie ma potrzeby jechać na turnus. Raczej na rodzinne wakacje, żeby i on po ciężkiej swojej pracy odpoczął. Teraz syn jest już nastolatkiem, nie ma już zajęć w OWI. I uważam, że teraz właśnie warto pojechać na turnus. Raz w roku to jest dla nas akurat. I do tego też oczywiście wspólny wakacyjny wyjazd wypoczynkowy już bez terapii. Choćby to miał być tylko wspólny weekend. Odkąd mamy subkonto, możemy w ten sposób organizować nasze wyjazdy.

Janina: Jeździłam z córką na turnusy, gdy była mała. Po czterech latach stwierdziłam, że czas z tym skończyć i żyć normalnie. Wyjeżdżaliśmy raz w roku na wspólny wyjazd rodzinny, czasami tylko ja i córka. Mogłam tak zadecydować, ponieważ córka ma zespół Downa i w pewnym momencie nie potrzebowaliśmy już tak intensywnej rehabilitacji. 
Większy odsetek rodziców zarówno w rodzinach z dzieckiem z niepełnosprawnością, jak i bez niepełnosprawności ocenia stopień zaspokojenia potrzeb związanych z wypoczynkiem poza miejscem zamieszkania negatywnie (raczej źle, źle). Jednak odsetek gospodarstw z dzieckiem niepełnosprawnym jest wyższy o 20,2 p.p. w porównaniu z drugą grupą rodziców (tabela 3).

Tabela 3. Poziom zaspokojenia potrzeby wypoczynku (\% gospodarstw)

\begin{tabular}{l|c|c|c|c|c|c}
\hline \multirow{2}{*}{ Rodzaj gospodarstwa } & \multicolumn{7}{c}{ Ocena } \\
\cline { 2 - 7 } & dobrze & $\begin{array}{c}\text { raczej } \\
\text { dobrze }\end{array}$ & $\begin{array}{c}\text { przeciętnie, } \\
\text { ani dobrze, } \\
\text { ani źle }\end{array}$ & $\begin{array}{c}\text { raczej } \\
\text { źle }\end{array}$ & źle & $\begin{array}{c}\text { nie } \\
\text { dotyczy }\end{array}$ \\
\hline $\begin{array}{l}\text { z dziećmi bez } \\
\text { niepełnosprawności }\end{array}$ & 14,7 & 15,1 & 28,7 & 18,8 & 20,1 & 2,6 \\
\hline $\begin{array}{l}\text { z dzieckiem z nie- } \\
\text { pełnosprawnością }\end{array}$ & 8,1 & 7,6 & 22,2 & 25,3 & 33,8 & 3,0 \\
\hline
\end{tabular}

Źródło: opracowanie własne na podstawie nieopublikowanych danych z BBGD 2014.

\section{Aktywność zawodowa}

Jan Paweł II zauważył: „Praca jest dobrem człowieka — dobrem jego człowieczeństwa - przez pracę bowiem człowiek nie tylko przekształca przyrodę, dostosowując ją do swoich potrzeb, ale także urzeczywistnia siebie jako człowiek, a także poniekąd bardziej staje się człowiekiem" (Encyklika 1982).

W wypadku rodziców z dzieckiem z niepełnosprawnością słowa te nabierają szerszego znaczenia. Praca bowiem nie tylko dostarcza środków do życia. Pomaga również w nawiązywaniu więzi międzyludzkich i relacji społecznych. W piramidzie potrzeb Abrahama H. Maslowa potrzeba przynależności jest trzecią, którą człowiek chce zaspokoić (po potrzebach fizjologicznych i bezpieczeństwa). Wykonywany zawód lokuje danego człowieka w strukturze społecznej; praca daje możliwość samorealizacji. Jeśli więc rodzic nie pracuje, jego relacje społeczne są niewielkie i nie zostaje zaspokojona potrzeba przynależności.

Dodatkowo w przypadku rodziców dziecka z niepełnosprawnością pracę należy potraktować jako możliwość odpoczynku od dziecka i skupienia się na innych problemach niż niepełnosprawność. Jednak tylko 37\% respondentów wskazało, że praca umożliwia oderwanie się (odpoczynek) od niepełnosprawnego dziecka (wykres 4). Tak niski odsetek odpowiedzi twierdzących można wythumaczyć tym, że matce w Polsce jest wstyd się przyznać do tego, że jest zmęczona swoim dzieckiem. Aż $67 \%$ respondentów podało, że praca to możliwość kontaktu z ludźmi, a około $60 \%$ stwierdziło, że praca daje możliwość rozwoju zawodowego i osobistego. 
Monika: Po urodzeniu Ani przez pierwszy rok bardzo intensywnie się nią zajmowałam. Potem musiałam coś zrobić dodatkowego, bo inaczej bym zwariowała. Ciągle to samo. Ci sami ludzie, te same problemy. Wszędzie dookoła niepełnosprawne dzieci. Poszłam najpierw na studia podyplomowe, które do dzisiaj są mi niepotrzebne. Ale pozwoliły mi nabrać dystansu. Poszukałam pracy i pracuję. Jednocześnie czuwam nad moją córką. Nie jest łatwo. Ale coś za coś. Dzięki pracy mam siłę dla dziecka ${ }^{5}$.

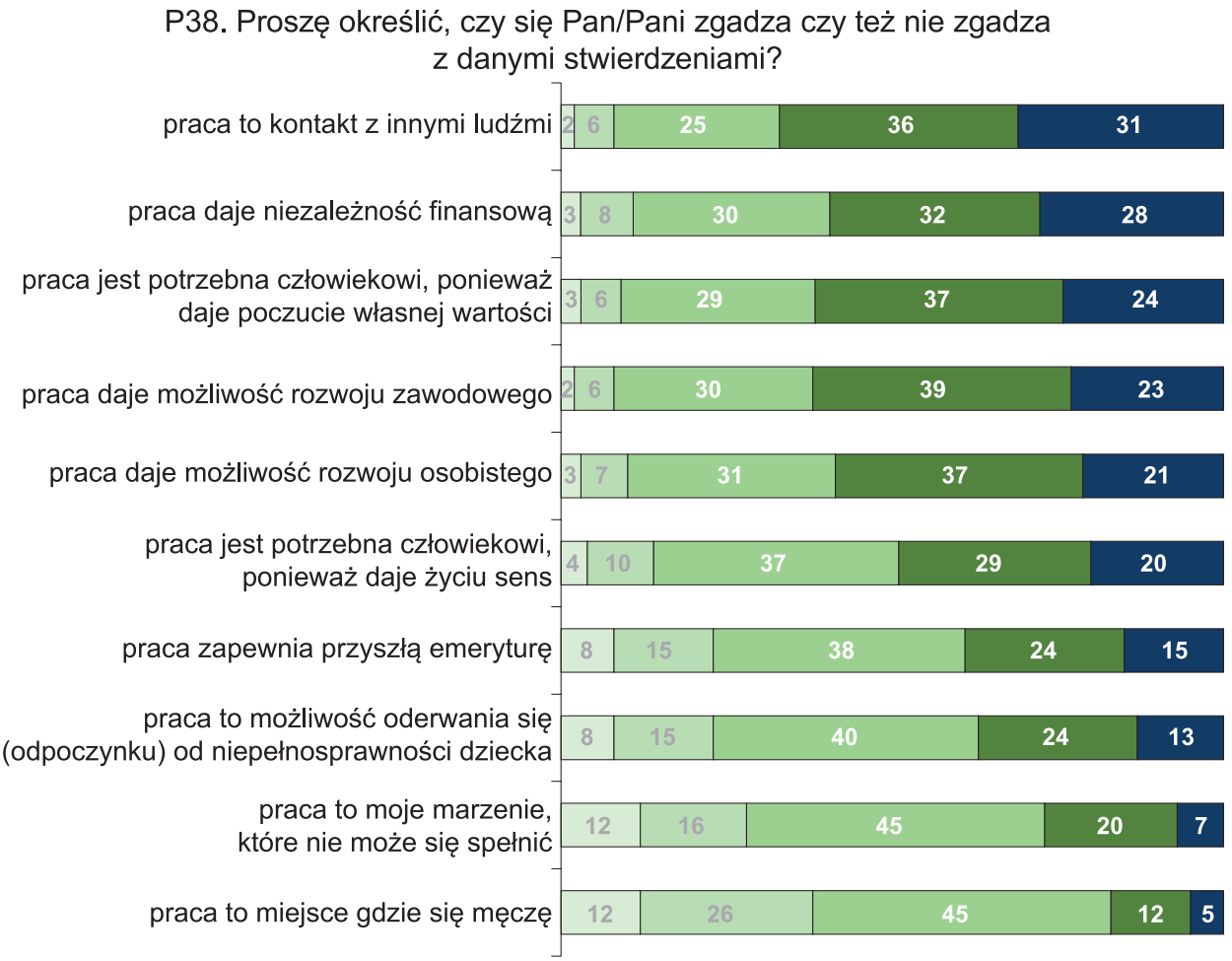

\section{zdecydowanie nie $\square$ raczej nie $\square$ ani tak ani nie $\square$ raczej tak $\square$ zdecydowanie tak}

$N=686$

Wykres 4. Znaczenie pracy dla rodziców dziecka z niepełnosprawnością

Źródło: opracowanie własne na podstawie danych z badania „Zachowania przedsiębiorcze i konsumpcyjne w rodzinach opiekujących się dziećmi i młodzieżą z niepełnosprawnością".

Katarzyna: Mam zaplecze finansowe. Dzięki temu stać mnie było, żeby dołożyć się do wózka czy do innych sprzętów rehabilitacyjnych. Lubię pracować z ludźmi. Mam zaplecze socjalne, dobre zaplecze socjalne. I to jest bardzo ważne. Bo to gdzieś tam w jakiejś dziedzinie życia daje mi spokój. Że tu się mogę skupić, nie muszę się o wszystko martwić, a tak tu brak pieniędzy, człowiek jest zdany sam na siebie, nie ma przyjaciół. Siedzi w tym domu skazany na to dziecko, bo to jest skazanie na dziecko. I obydwoje zaczynają się zapętlać - matka z dzieckiem. I obydwoje zaczynają fiksować. No bo tak jest w większości, niestety. kułu.

5 Wywiad przeprowadzony w 2010 roku w ramach badań do pracy doktorskiej autorki arty- 
We wskazanym kontekście należy zwrócić uwagę na dysproporcję w aktywności zawodowej matek dzieci bez niepełnosprawności i z niepełnosprawnością. Kobiety pracujące zawodowo stanowiły $41 \%$ wszystkich matek, które wychowują dziecko z niepełnosprawnością. Natomiast kobiety, które wychowują dziecko pełnosprawne i jednocześnie pracują, stanowiły $71,6 \%$ swojej grupy. Różnica pomiędzy dwiema grupami matek to 30 p.p.

\section{Zakończenie}

Rodzina odgrywa niezwykle ważną rolę w procesie wychowania i wspierania dziecka (Obuchowska 1991, s. 18). W wypadku diagnozy niepełnosprawności u dziecka jego opiekunowie (rodzice) stają przed nowymi wyzwaniami i obciążeniami zarówno ze strony psychicznej i fizycznej, jak i finansowej i organizacyjnej. Pojawia się stres, często wypalenie się sił.

Analiza danych liczbowych i wywiadów z rodzicami pokazała, że z jednej strony w badanych rodzinach występuje niska aktywność życiowa w weekendy i w święta, z drugiej - potrzeba kultury ${ }^{6}$, czyli na przykład wyjścia do kina, jest bardzo słabo zaspokojona. Jako główny powód słabej aktywności rodzice podają finanse. Można jednak przypuszczać, że w czasach gdy dużo imprez organizowanych jest przez samorządy, dzięki czemu są one darmowe, powodem niskiej aktywności w weekendy i święta jest zmęczenie rodziców, słabe kontakty społeczne, zamknięcie się w świecie niepełnosprawności. Przyczyną może być również niemożność pozostawienia dziecka w domu bez czyjegoś wsparcia. Duża część rodziców sprawuje bowiem opiekę nad swoim dzieckiem przez cały rok, niezależnie od wieku dziecka. Przykładowo, w 2014 roku 36\% rodziców nie wyjechało ani razu poza miejsce zamieszkania. Czas wolny rodzic ma dla siebie, gdy dziecko przebywa pod opieką, to znaczy, gdy jest na przykład w przedszkolu, szkole albo kiedy ktoś sprawuje nad nim opiekę. Nie pracuje 50\% matek opiekujących się dzieckiem z niepełnosprawnością.

Wnioski te pokazują, że potrzebne jest wsparcie rodzin z dzieckiem z niepełnosprawnością w celu zapewnienia im czasu wolnego, wypoczynku i oderwania się od niepełnosprawności. Żeby dziecko czuło się kochane, rodzic musi mieć do tego siłę. Gdy jest zmęczony, sfrustrowany i wypalony, nie poświęci należytej uwagi dziecku. Do prawidłowego rozwoju dziecka potrzebne są bowiem nie tylko zajęcia terapeutyczne, lecz także miłość i akceptacja. W dodatku rodzic będzie zajmował się dzieckiem z niepełnosprawnością intelektualną również w sytuacji, gdy będzie ono już pełnoletnie. Musi mieć do tego siły, a sam nie wybrał dla siebie takiej drogi życiowej.

W grudniu 2016 roku w Polsce został ustanowiony program „Za życiem”, którego celem jest wsparcie rodzin z osobami niepełnosprawnymi, w tym wycho-

${ }^{6}$ Zakup książek i czasopism, wyjście do kina, teatrów, na koncerty itp. 
wującymi niepełnosprawne dziecko. Chociaż w programie tym po raz pierwszy zwrócono w naszym kraju uwagę na potrzebę wsparcia ze strony państwa na aktywność zawodową matek wychowujących dziecko z niepełnosprawnością i zapewnienie im wypoczynku od opieki, to wymienione w tym programie rozwiązania nie będą odpowiedzią na wszystkie problemy z tym związane. Należy zatem w dalszym ciągu konsultować rozwiązania systemowe i rozwijać zakres pomocy.

\section{Bibliografia}

Bujak E. (2013), Zjawisko ,wypalenia się sit” u matek dzieci niepetnosprawnych, „Rozprawy Społeczne" 7, nr 2, s. 112-118.

Encyklika Ojca Świętego Jana Pawła II o pracy ludzkiej „Laborem exercens” (1982), Warszawa, http://www.opoka.org.pl/biblioteka/W/WP/jan_pawel_ii/encykliki/laborem.html (dostęp: 15.07.2017).

Giddens A. (2008), Socjologia, Warszawa, s. 305-319.

Gitling M. (2013), Człowiek i jego praca, „Nierówności Społeczne a Wzrost Gospodarczy” 33, s. $211-221$.

Komorowska O. (2014), Rodzice zdani na siebie, „Rzeczpospolita” 8.04., s. A12.

Komorowska O. (2016), Aktywność zawodowa i jej determinanty wśród matek wychowujacych dziecko z niepetnosprawnościa, [w:] Współczesne problemy rodzin z dziećmi z niepetnosprawnościa w Polsce, red. O. Komorowska, M. Janoś-Kresło, Warszawa, s. 21-34.

Kosmalowa J. (2007), Problemy rodziców dzieci z niepetnosprawnościa, [w:] Rodzina - normalność w niepetnosprawności, red. D. Gorajewska, Warszawa, s. 109-115.

Kubicki P. (2016), Aktywność zawodowa i społeczna rodziców dzieci z orzeczona niepetnosprawnościa w kontekście systemu wsparcia — refleksje i rekomendacje, [w:] Współczesne problemy rodzin z dziećmi z niepetnosprawnościa w Polsce, red. O. Komorowska, M. Janoś-Kresło, Warszawa, s. 13-15.

Obuchowska I. (1991), Dziecko niepetnosprawne w rodzinie, Warszawa, s. 18.

Sekułowicz M., Kwiatkowski P. (2013), Wypalenie się u rodziców dzieci z niepetnosprawnościa konstrukcja nowego narzędzia badawczego, „Studia Edukacyjne” nr 20, s. 29-50.

Truszkowska-Wojtkowiak M. (2012), Fenomen czasu wolnego, Gdańsk, s. 196-212. 